\title{
Alterations in the expression of the apurinic/apyrimidinic endonuclease-1/redox factor-1 (APE1/Ref-1) in human ovarian cancer and indentification of the therapeutic potential of APE1/Ref-1 inhibitor
}

\author{
YING ZHANG $^{1}$, JIAN WANG ${ }^{1}$, DEBING XIANG $^{2}$, DONG WANG $^{2}$ and XIAOYAN XIN ${ }^{1}$ \\ ${ }^{1}$ Department of Gynaecology and Obstetrics, Xijing Hospital, Fourth Military Medical University, Xi'an 710032; \\ ${ }^{2}$ Cancer Center, Daping Hospital, Third Military Medical University, Chongqing 400042, P.R. China
}

Received April 7, 2009; Accepted June 22, 2009

DOI: 10.3892/ijo_00000422

\begin{abstract}
Resistance to platinum is a major limitation for the treatment of ovarian cancer. In an effort to overcome the platinum resistance problem in ovarian cancer treatment, we explored the correlation between cisplatin resistance and the human AP endonuclease (APE1 or Ref-1). APE1/Ref-1 is a multifunctional protein that is not only an essential enzyme in base excision repair pathway, but also acts as a major redox-signaling factor that has a wide variety of important cellular functions including transcription factor regulation, oxidative signaling and cell cycle control. In this study, we examined APE1/Ref-1 expression by immunohistochemistry in sections of ovarian cancers from 78 patients who were administered standard adjuvant chemotherapy based on platinum post-operatively. Altered levels and subcellular APE1/Ref-1 expression was found in patients not responding to platinum-based chemotherapy comparing with those who responded to platinum-based chemotherapy. Meanwhile, we detected the APE1/Ref-1 expression in A2780 and CP70 cell lines which have different sensitivity to cisplatin. We found similar altered APE1/Ref-1 expression in them. We hypothesized that the APE1/Ref-1 expression is responsible in part for the cisplatin resistance. To answer this hypothesis, we decreased the APE1/Ref-1 level by silencing RNA targeting technology in A2780 and CP70 cell lines. The A2780 cells treated with APE1-siRNA had $\mathrm{IC}_{50}$ values ranging from 6.70 to $1.74 \mu \mathrm{M}$ cisplatin compared with $15.81 \mu \mathrm{M}$ for
\end{abstract}

Correspondence to: Dr Xiao-Yan Xin, Department of Gynaecology and Obstetrics, Xijing Hospital, Fourth Military Medical University, Xi'an, 710033, P.R. China

E-mail: anran206@fmmu.edu.cn

Dr Dong Wang, Cancer Center, Daping Hospital and Research Institute of Surgery, Third Military Medical University, Chongqing 400042, P.R. China

E-mail: dongwang64@hotmail.com

Key words: cisplatin, ovarian cancer, apurinic/apyrimidinic endonuclease, siRNA control A2780 cells. The CP70 cells treated with APE1siRNA had 1.62-4.63-fold enhancement in cisplatin sensitivity. The apoptosis assays using TUNEL analysis showed that decreased APE1/Ref-1 level resulted in increased apoptosis levels in A2780 and CP70 cell lines compared with the control-treated cells. These data suggest that APE1/ Ref-1 levels play an important role in the sensitization of ovarian cancer cells to apoptosis. In vitro studies revealed that it is possible to substantially enhance the cisplatin cytotoxicity by decreasing APE1/Ref-1 level in cisplatin-resistant cell lines.

\section{Introduction}

According to new statistics offered by the American Cancer Society, ovarian cancer is the fifth cause of death from cancer in women and the leading cause of death from gynecological cancer. In 2008, it is estimated that there will be 21,650 new ovarian cancer cases in the USA (1). More than $70 \%$ of ovarian cancer cases present with advanced stage of disease at diagnosis. Despite combination chemotherapy yielding complete responses in $60-80 \%$ of patients with advancedstage disease, $\sim 25 \%$ of patients show intrinsic resistance to the first line chemotherapy, and the majority of patients eventually relapse and become refractory to additional treatments. Therefore, chemoresistance to chemotherapy is considered a major obstacle in attempts to improve the clinical outcome of ovarian carcinoma patients (2).

Platinum-based chemotherapy is the primary treatment for ovarian cancer and is also used in a wide variety of other malignancies. The cytotoxic lesion of platinate agents is thought to be the platinum intrastrand crosslink that forms on DNA, although treatment activates a number of signal transduction pathways (3). However, the overall clinical success of platinum is somewhat diminished by intrinsic and acquired tumor resistance. Platinum-resistance is multifactorial and rather complicated. There are several possible cellular responses to such potentially cytotoxic insults, including induction of apoptosis, modulation of cell cycle progression, tolerance of damage and initiation of DNA repair. The ability to repair cisplatin-DNA adducts and tolerate great levels of 
DNA damage determines the cell fate, whether it will survive or initiate programmed cell death.

Recently, more evidence suggests that the human apurinic/ apyrimidinic endonuclease 1/redox factor-1 (APE1 or Ref-1), one of the key enzymes in the base excision repair pathway, may play a crucial role in the development of chemoresistance. APE1/Ref-1 is an essential endonuclease which is responsible for the repair of abasic sites caused by oxidative and alkylation damage. The removal of a damaged base results in an AP site that, if it fails to repair, may lead to DNA strand breaks, apoptosis and an increase in cytotoxicity. In addition to AP endonuclease activity, APE1/Ref-1 has 3'-repair diesterase or phosphatase activity, albeit at 200-fold lower than its AP endonuclease activity (4). APE1/Ref-1 also possesses $3^{\prime}-5^{\prime}$ exonuclease activity which plays a role in the excision of deoxyribonucleoside analogs from DNA $(5,6)$. The inhibition of this activity could have implications in treating cancers when nucleoside analogs such as gemcitabine are used.

In addition to the repair role of APE1/Ref-1, it also functions as a transcriptional coactivator by both redoxdependent and -independent mechanisms, to reduce and activate transcription factors such as AP-1, p53, HIF-1 and others transcription factors that participate in some crucial cellular processes, including the response to oxidative stress, regulation of transcription factors, cell cycle control and apoptosis (4). Thus, the function of APE1/Ref-1 protein is involved in DNA repair, growth-signaling pathways and pathways involved in tumor promotion and progression.

Several studies demonstrated a strong upregulation level of APE1/Ref-1, which was always observed in several human tumors, such as ovarian cancer, cervical cancer, non-small cell lung cancer and osteosarcoma (7-10). Furthermore, more recent analysis shows APE1/Ref-1 levels of expression are correlated with cancer tissue's sensitivity to radiation therapy and chemotherapy. Moreover, elevated APE1/Ref-1 protein level is associated with poor clinical outcome $(7,10-12)$. Based on the studies mentioned, it is clear that the APE1/Ref-1 protein is fundamental to the maintenance of the genome and survival of cells. In this study, we assess the relevance between APE1/ Ref-1 protein and cisplatin drug-resistance in epithelial ovarian cancer cell lines as well as in primary ovarian tumors. We also investigated if supressed APE1/Ref-1 protein level can enhance the sensitivity of cancer cells to cisplatin.

\section{Material and methods}

Patients and tissues. Tumor tissues were obtained from 78 patients with primary epithelial ovarian cancer at the Department of Obstetrics and Gynecology Xijing Hospital, Fourth Military Medical University and Cancer Center, Daping Hospital, Third Military Medical University from 1998 to 2004. Local ethics committees approved the study. Patients with benign and non-epithelial tumors, borderline tumors and recurrent disease were excluded from the study. Tissue specimens were taken intraoperatively, formalin-fixed and paraffin-embedded. No chemotherapy or radiotherapy was given to patients before surgery. In these cases, standard adjuvant chemotherapy based on platinum was applied postoperatively, and the clinical outcome was available. The mean observation time was $52 \pm 25$ months. The age range of the patients was 19 to 81 years (mean: $47.16 \pm 11.5$ ). The 78 cases included 33 serous cystadenocarcinoma, 34 mucous cystadenocarcinoma, 6 endometrial carcinoma and 5 undifferentiated carcinoma.

Platinum sensitivity was defined by response to first-line platinum chemotherapy or a progression-free interval of $>6$ months off treatment. Patients who progressed during treatment, had stable disease in response to initial platinumbased therapy, or those who relapsed within 6 months were considered to have platinum-refractory disease. Criteria for persistence or recurrence included clinical evidence of disease (e.g. physical examination findings or measurable disease on computed tomography or magnetic resonance imaging) or a sustained rise in serum CA-125.

Cell culture. The human ovarian epithelial adenocarcinoma cell lines, A2780 and CP70, were kindly provided by Dr Jia Luo (Institute for Nutritional Science, Shanghai, China). A2780 is an ovarian cancer cell line established from tissue obtained from an untreated ovarian cancer patient. Cisplatinresistance cell lines CP70 were produced by intermittent exposure of the sensitive parental A2780 cell line to stepwiseincreasing concentrations of cisplatin. Cells were maintained as monolayer cultures in DMEM, supplemented with $10 \%$ fetal bovine serum, $100 \mathrm{U} / \mathrm{ml}$ penicillin, $100 \mu \mathrm{g} / \mathrm{ml}$ streptomycin and $0.3 \mathrm{mg} / \mathrm{ml}$ glutamine. Cells were grown at $37^{\circ} \mathrm{C}$ in a humidified incubator under $5 \% \mathrm{CO}_{2}$.

Immunohistochemical analysis of tumors for APE1 expression. Cellular localization of APE1/Ref-1 was determined by using imunohistochemical staining. Immunohistochemistry was performed on formalin-fixed, paraffinembedded sections. Tissue specimens were cut into $4 \mu \mathrm{M}$ sections from representative tumor and non-tumor blocks. After blocking endogenous peroxidase with $3 \% \mathrm{H}_{2} \mathrm{O}_{2}$ methanol for $10 \mathrm{~min}$, tumor sections were coated with the primary antibody (mouse APE1 monoclonal antibody; Novus Biologicals, Littleton, CO) diluted 1:200 in PBS. Slides were incubated overnight at $4^{\circ} \mathrm{C}$. The next day, sections were rinsed three times for $5 \mathrm{~min}$ in PBS and incubated with a 1:200 dilution of horseradish peroxidase conjugated, goat anti-mouse immunoglobulin G antibody (Pierce, Rockford, IL, USA) for $30 \mathrm{~min}$. After two PBS washes for $5 \mathrm{~min}$ each, the sections were developed with DAB solution for $10 \mathrm{~min}$. After the development of color signal, the sections were washed briefly in distilled $\mathrm{H}_{2} \mathrm{O}$, counterstained with eosin, dehydrated through a graded alcohol to xylene sequence, coverslipped. Then, they were counterstained with haematoxylin. Negative control slides for APE1/Ref-1 antibody were prepared from the same tissue block which contains preimmune $\operatorname{IgG}$ as the primary antibody.

Slides were evaluated by counting at least 100 cells in two different areas of the specimens. They were classified according to nuclear staining, cytoplasmic staining and staining of stroma cells. Evaluation of nuclear staining was done by determination of the percentage of stained nuclei and the intensity of nuclear staining that was classified into four categories $(0,1,2$ and 3 corresponding to negative, weak, intermediate and strong). Similarly, the intensity of cytoplasmic staining and the stromal elements was classified into 
the categories $0-3$. With respect to sub-cellular localization and percentage of immunoreactive cells, each tumor was classified as 'cytoplasmic' or 'non cytoplasmic'. All investigations were performed under a microscope with chiffrelabeled slides. Slides were checked, in parallel, by a pathologist for confirmation of tumor and normal tissue which was under investigation.

Western blot analysis. Western blots of A2780 and A2780/ CP70 cells were performed by utilizing whole-cell extracts electrophoresed on 12\% SDS-PAGE and electroblotted onto $0.2 \mathrm{~mm}$ nitrocellulose. Protein levels in the extracts were quantitated with the Bio-Rad protein assay reagent (Bio-Rad, Hercules, CA), and equal amounts $(20 \mu \mathrm{g})$ of protein were loaded/lane. Equal protein aliquots in each sample were resolved in $12 \%$ sodium dodecyl sulfate polyacrylamide gel electrophoresis (SDS-PAGE) and the proteins transferred onto PVDF membranes. After blocking with 5\% non-fat dried milk, the membranes were incubated with a 1:2,000 dilution of primary mouse monoclonal antibodies against human APE1, $\beta$-actin and retinoblastoma $(\mathrm{Rb})$. The membranes were then incubated with a horseradish peroxidaseconjugated secondary antibody $(1: 2,000)$ (Pierce). The proteins were detected by an enhanced chemiluminescence detection system (Pierce), and light emission was captured on Kodak $\mathrm{X}$-ray film.

Infection with adenoviruses and flow cytometry. The APE1 siRNA expression vector named Ad5/F35-APE1 siRNA was constructed by De-Bing Xiang (13). The titer was $1.6 \times 10^{10}$ $\mathrm{IU} / \mathrm{ml}$ after amplication and purfication. A2780 and CP70 cell lines were infected with Ad5/F35-EGFP or Ad5/F35APE1 siRNA with increasing multiplicities of infection (MOI) for $90 \mathrm{~min}$ and were then washed to remove the adenoviruses. They were cultured for $24 \mathrm{~h}$ and then analyzed by Western blot and MTT assay or repared for following experiments.

Cytotoxicity assays: MTT assay. Cisplatin cytotoxicity was determined by the microculture tetrazolium (MTT) assay. Cells were plated at 1000 cells/well in 96-well plates in triplicate for each dose and allowed to adhere overnight. Cisplatin was dissolved in PBS without $\mathrm{Ca}^{+}$or $\mathrm{Mg}^{+}$at $1.0 \mathrm{mg} / \mathrm{ml}$ (3.33 mM cisplatin), and dilutions from this solution was made in media to obtain the desired drug treatment concentrations ranging from 5 to $100 \mu \mathrm{M}$. After incubation for $48 \mathrm{~h}$ in various cisplatin concentrations, washed with PBS and fresh medium added. After $72 \mathrm{~h}, 40 \mu \mathrm{l}$ of $5 \mathrm{mg} / \mathrm{ml} \mathrm{3-(4,5-}$ dimethylthiazol-2-yl)-2,5-diphenyltetrazolium bromide (MTT) were added per well and incubated at $37^{\circ} \mathrm{C}$ for $2 \mathrm{~h}$, then the medium was then removed, the cells were lysed with $100 \mu \mathrm{l} /$ well of lysis butter [20\% (w/v) SDS-50\% N, Ndimethylformamide ( $\mathrm{pH} 4.7)]$. The absorbance at $570 \mathrm{~nm}$ was measured by using wells without cells as blanks. $\mathrm{IC}_{50}$ was used as the measure of relative cytotoxicity. The fold enhancement in cisplatin sensitivity was considered to be the ratio of the $\mathrm{IC}_{50}$ of the parental cell line to APE1 siRNA transfected cell lines.

In situ apoptosis detection by TUNEL staining. To detect apoptosis, cells on glass coverslips were analyzed by in situ terminal dUTP nick end-labeling (TUNEL) by using the Chromogenic TUNEL-POD (Roche Diagnostics, Indianapolis, IN) assay following the manufacturer's protocols. The coverslips were first fixed in 4\% paraformaldehyde in PBS, $\mathrm{pH} 7.4$, freshly prepared, after which incubated for $15 \mathrm{~min}$ at room temperature with $0.1 \%$ Triton $\mathrm{X}-100$ in $0.1 \%$ sodium citrate, freshly prepared in order to permeabilisation. After the coverslips were rinsed twice with PBS, $50 \mu 1$ TUNEL reaction mixture was added on samples. Coverslips were add lid and incubated for $60 \mathrm{~min}$ at $37^{\circ} \mathrm{C}$ in a humidified atmosphere in the dark. Rinsed slides three times with PBS, and add $50 \mu 1$ DAB substrate. TUNEL positive cells were identified by their dark brown staining. The frequency of apoptotic cells was evaluated by counting approximately 1000 cells at x400.

Cell cycle analysis. Treated cells were harvested by trypsinization and were washed twice with PBS, fixed in $70 \%$ alcohol, and stored at $4^{\circ} \mathrm{C}$. The PBS washed cells were subsequently rinsed with $0.2 \mathrm{M}$ phosphate-citrate buffer at $\mathrm{pH} 7.8$. Then, the cells were stained with $200 \mu \mathrm{l}$ staining solution $(20 \mu \mathrm{g}$ $\mathrm{PI} / \mathrm{ml} \mathrm{PBS}+$ ribonuclease A (DNA-free; $5 \mathrm{U} / \mathrm{ml}$; both SigmaAldrich Corp.) for $30 \mathrm{~min}$ at $37^{\circ} \mathrm{C}$ in the dark. The DNA content of the cells was analyzed by utilizing flow cytometry (FACSCalibur $^{\mathrm{TM}}$, Becton-Dickinson, $488 \mathrm{~nm}$ argon laser for excitation). For each sample, $5 \times 10^{5}$ cells were acquired, and the percentages of cells in individual cell cycle phases were analyzed with ModFit 2.0 software (Verity Software House). Single cell was identified and gated by pulse-code processing of the area and the width of the fluorescence signal. Cell debris was excluded by appropriated increase of the forward scatter threshold.

Statistical analysis. Data were expressed as the mean and SD. Associations between categorical groups (i.e., APE1related protein expression and clinicopathological variables) were tested using Chi-square test. The statistical significance of differences was determined by the Student's two tailed t-test in two groups and by one way ANOVA in multiple groups. A value of $\mathrm{p}<0.05$ was considered statistically significant. Statistical analysis was performed by using SPSS 16.0 for Windows (SPSS Inc., Chicago, IL).

\section{Results}

Ovarian carcinoma immunohistochemistry and clinicopathologic parameters. The distribution of APE1/Ref-1 in ovarian cancer tissues is presented in Fig. 1. Three subcellular locations of APE1/Ref-1 protein were observed, which were nucleus staining in 53 cases $(67.95 \%)$, cytoplasm staining in 7 cases $(8.97 \%)$ and staining in both the nucleus and cytoplasm in 18 cases $(23.08 \%)$. The APE1/Ref-1 staining of the nucleus was predominant but not uniform. In cancer samples, strong nuclear expression of APE1/Ref-1 was found in 13 cases $(24.53 \%)$, moderate in 29 cases $(54.72 \%)$ and weak in 10 cases $(18.87 \%)$. In the cytoplasm staining $(32.05 \%)$, most samples showed an intermediate intensity $(81.82 \%)$.

APE1/Ref-1 immunopositivity and chemosensitivity to platinum-based chemotherapy. To examine the association of APE1/Ref-1 expression with response to chemotherapy in 


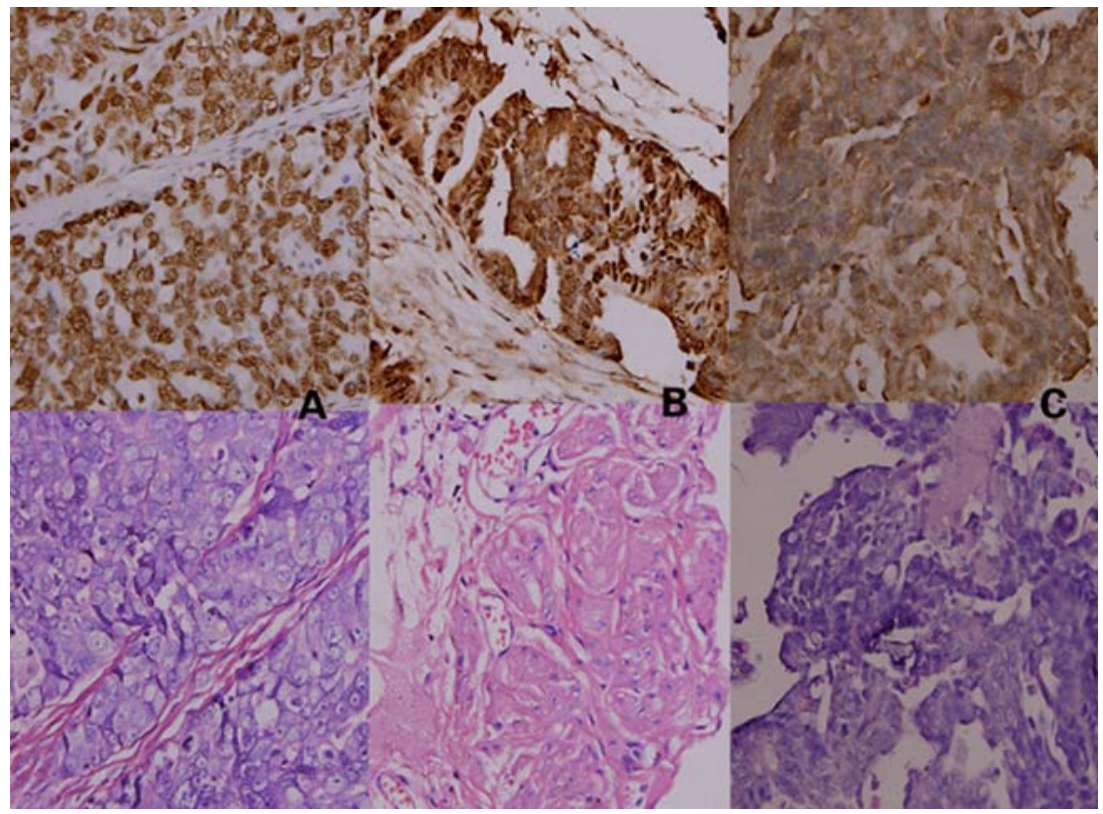

Figure 1. Representative APE1/Ref-1 immunostaining of primary ovarian carcinomas. Nuclear reactivity (A), both nuclear and cytoplasmic reacitivity (B) and cytoplasmic reactivity $(\mathrm{C})$.

primary ovarian cancer, we analyzed the APE1/Ref-1 expression of 78 primary ovarian carcinoma patients with standard platinum-based chemotherapy after debulked operation. Although the majority of the tumor specimens demonstrated variation in the staining intensity, ovarian cancer tissues also displayed strikingly different patterns of APE1/Ref-1 expression between different responses to platinum-based chemotherapy: numerous cells showed APE1/ Ref-1 staining in the nucleus in the platinum sensitive patients we studied, while platinum-resistance patients exhibited more disperse cytoplasm staining.

In Fig. 2A the association between APE1/Ref-1 intensity and responses to chemotherapy in the overall series is also summarized: $8(38.10 \%)$ of the non-responding cases showed high level of APE1/Ref-1 expression, while in patients responding to chemotherapy APE1/Ref-1 high level expression was found in 9 out of $57(15.79 \%)$ patients $(\mathrm{p}<0.05)$.

As shown in Fig. 2B, in the group of patients administered platinum-based chemotherapy, APE1/Ref-1 nuclear location was found in 10 out of $21(47.62 \%)$ of nonresponding patients vs. 42 out of $57(73.68 \%)$ of responding patients. On the other hand, APE1/Ref-1 cytoplasm was found in a statistically significant higher percentage of nonresponding cases than in patients responding to chemotherapy $(n=11 / 21 ; 52.38 \%$ vs. $n=15 / 57 ; 26.32 \%$; $p<0.05)$.

Expression of human APE1/Ref-1 in ovarian cancer cell lines. We also investigated the role of APE1/Ref-1 in the cisplatin-sensitive (A2780) and cisplatin-resistant ovarian cancer cells (CP70) by immunohistochemistry and Western blot analysis. As shown in Fig. 3A, the predominant pattern of APE1/Ref-1 expression in A2780 cell line was nuclear. By contrast, mixed nuclear/cytoplasmic expression was observed in CP70 cell line. APE1 protein expression level was noticeably higher in $\mathrm{CP} 70$, the cisplatin-resistant cell line. As shown in Fig. 3B, the result of Western blot had a similar difference between A2780 and CP70 cell lines. Analyzed by using Quantity One software of Bio-Rad company, the CP70 cells displayed a 1.3-fold higher APE1/Ref-1 overexpression compared with A2780 cells.

Cisplatin treatment-elevated APE1/Ref-1 expression in A2780 and CP70 cell lines. To determine whether APE1/Ref-1 expression correlated with cisplatin resistance, cells were incubated with variance from 5 to $40 \mu \mathrm{M}$ for $48 \mathrm{~h}$, respectively. Cell lysates were analyzed by Western blotting. As shown in Fig. 4, after different durations of cisplatin, in both cell lines APE1/Ref-1 content increased in a dose-dependent manner $(\mathrm{p}<0.05)$. The changes of APE1/Ref- 1 content in A2780 cells are more significantly compared with CP70 cells.

Ad5/F35-APE1 siRNA supresses APE1/Ref-1 expression in vitro. Following the treatment with Ad5/F35-APE1 siRNA, expression of APE1 protein was detected by Western blot analysis and immunohistochemistry in A2780 and CP70 cell lines. As shown in Figs. 5A and B, a dose-dependent decrease in APE1/Ref-1 protein expression was observed $48 \mathrm{~h}$ after infected with Ad5/F35-APE1 siRNA in A2780 and CP70 cell lines, and APE1 protein expression level declined in excess of $90 \%$ with $40 \mathrm{MOI}$ of Ad5/F35-APE1 siRNA; while no change was observed after Ad5/F35-EGFP infection in control group.

In another series of experiments, we investigated the expression of APE1/Ref-1 protein in A2780 and CP70 cell lines post-injection of 40 MOI of Ad5/F35-APE1 siRNA by immunohistochemistry. Cells were collected at 24 and $48 \mathrm{~h}$, respectively, after infected with adenoviruses. APE1/Ref-1 expression was apparently inhibited by the pretreatment with Ad5/F35-APE1 siRNA in a time-dependent manner (Fig. 5C).

Cisplatin sensitivity after Ad5/F35-APE1 siRNA treatment in vitro. To determine the impact of APE1/Ref-1 downregulation on cell survival in response to cisplatin, MTT assays 
A

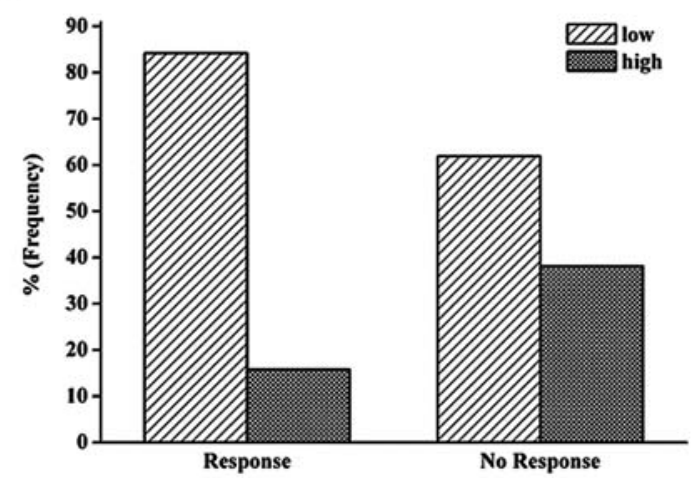

B

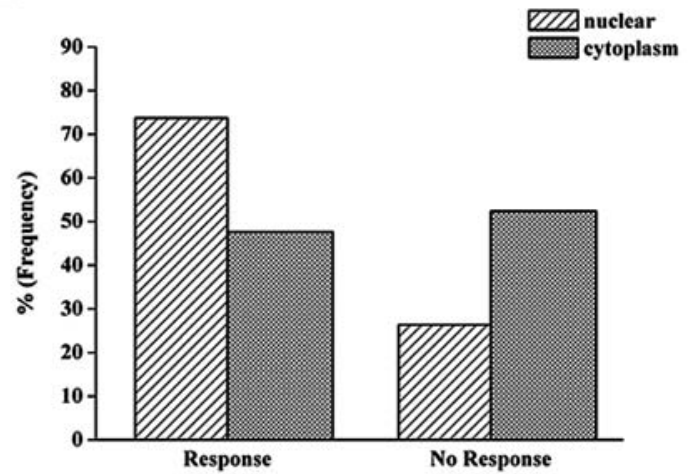

Figure 2. Correlation of APE1/Ref-1 expression with chemosensitivity to platinum-based chemotherapy. A, the frequency of intensity in responding and nonresponding patients; B, the frequency of subcellular location of APE1/Ref-1 in responding and non-responding patients.

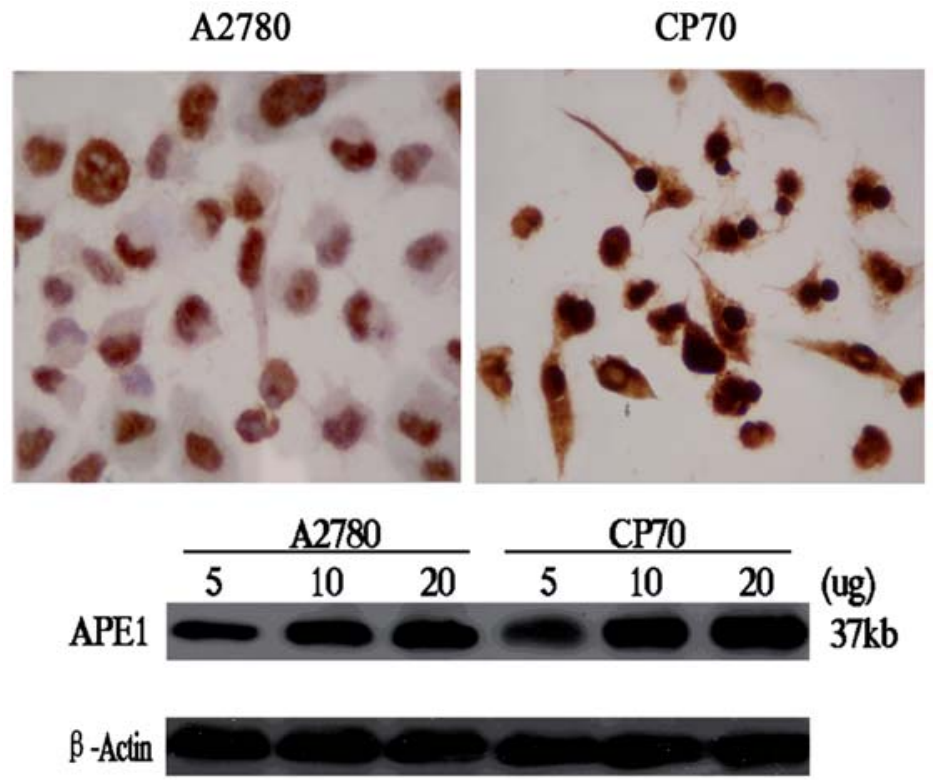

Figure 3. Expression of APE1/Ref-1 protein by immunohistochemical staining and Western blot analysis. APE1/Ref-1 protein was detected in ovarian cancer cell lines A2780 and CP70 with APE1/Ref-1 monoclonal antibodies. The APE1/Ref-1 antibody staining was predominantly localized in the nucleus of A2780 cells, whereas mixed nuclear/cytoplasmic expression was observed in CP70 cell line. In CP70 cells APE1/Ref-1 expression showed higher level compared with A2780 cells.

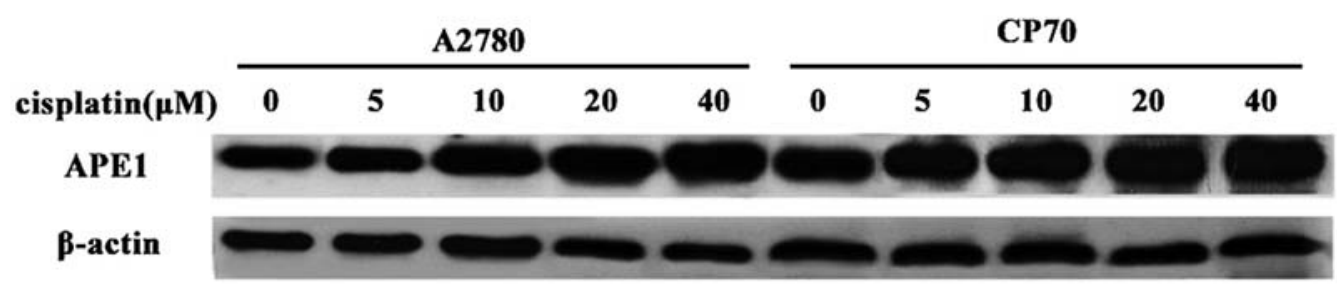

Figure 4. Cisplatin upregulated the APE1/Ref-1 level in a dose-dependent manner in A2780 and CP70 ovarian cancer cells. Cells were treated with different concentration of cisplatin for $48 \mathrm{~h}$, respectively. Experiments were repeated at least 3 times independently.

were employed for adenovirus and control cells. The cells were treated with cisplatin, recombinant Ad5/F35-APE1 siRNA and cisplatin, respectively. The cell in control group was treated with the empty adenoviral vector named Ad5/ F35-EGFP. MTT assay analysis showed a significantly reduced cell survival with APE1 inhibition (Fig. 6). The A2780 cell lines treated with APE1-siRNA had IC $_{50}$ values ranging from 6.70 to $1.74 \mu \mathrm{M}$ cisplatin compared with 15.81 $\mu \mathrm{M}$ for control A2780 cells. The CP70 cell lines treated with APE1-siRNA had 1.62-4.63-fold enhancement in cisplatin 
A

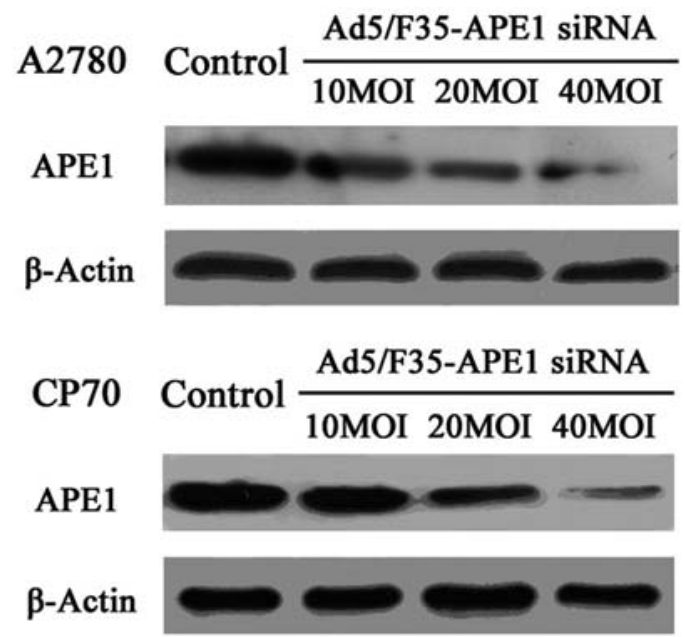

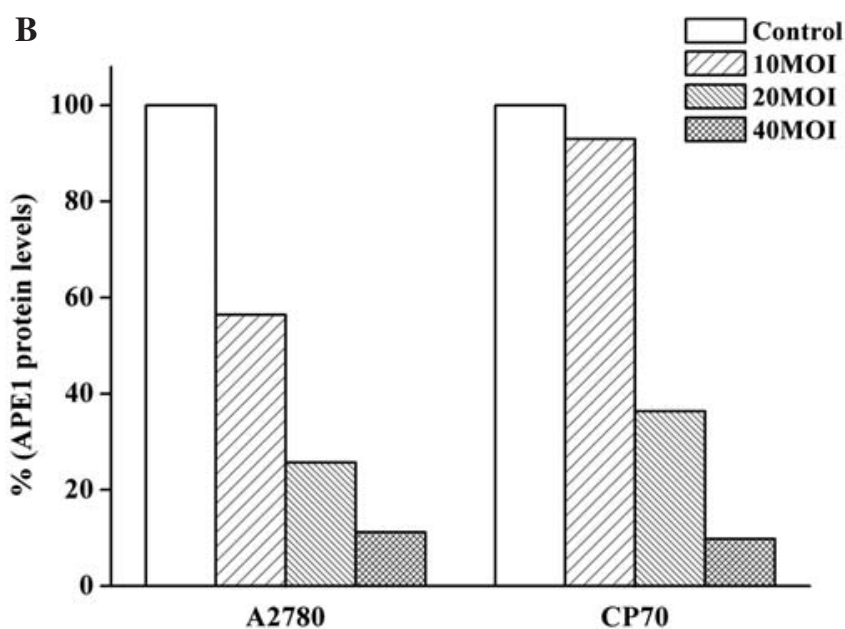

Ad5/F35-APE1 siRNA (40MOI)

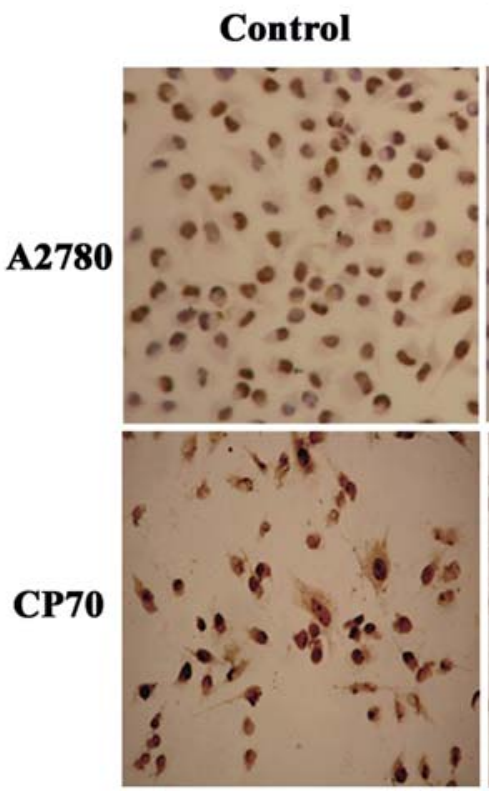

24 hours
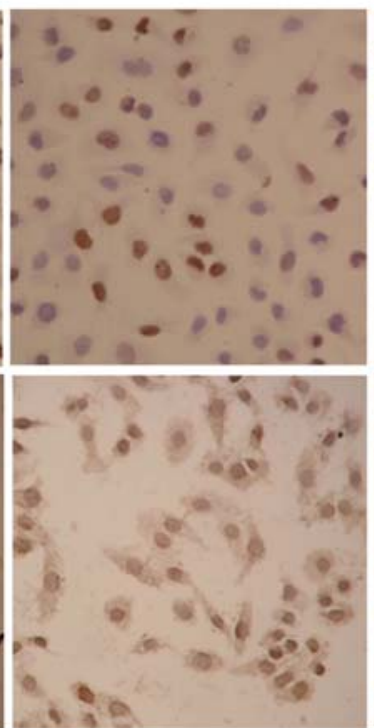

48 hours

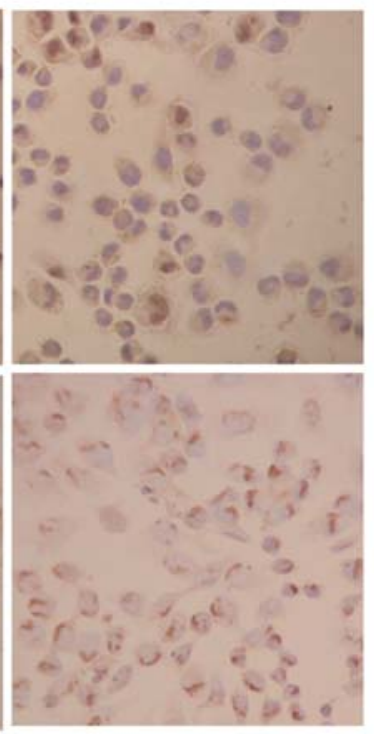

Figure 5. Knockdown of APE1 levels using RNA interference (siRNA). A, Western blot of A2780 and CP70 cells treated with APE1 siRNA. Samples were collected $48 \mathrm{~h}$ after APE1-siRNA treatment, and Western blot was done with APE1 monoclonal antibody and reprobed with actin antibody as a loading control. B, normalized APE1/Ref-1 levels after adjusting for loading. C, immunohistochemistry of A2780 and CP70 cells treated with APE1 siRNA. After infection with $40 \mathrm{MOI}$ of Ad5/F35-APE1 siRNA, APE1/Ref-1 protein assay were detected at 24 and $48 \mathrm{~h}$, respectively.

sensitivity $(\mathrm{p}<0.05)$, which indicates a protective effect of APE1/ Ref-1 on cisplatin-induced apoptosis.

Cell apoptosis after Ad5/F35-APE1 siRNA treatment in vitro. We investigated the impact of Ad5/F35-APE1 siRNA and cisplatin combination therapy on A2780 and CP70 cell lines. Cells were treated with an empty adenoviral vector (Ad5/ F35-EGFP) or Ad5/F35-APE1 siRNA, and cisplatin- IC $_{50}$ concentration) treated. The effects of Ad5/F35-APE1 siRNA on apoptosis induction by cisplatin were measured by TUNEL assay. As shown in Fig. 7, Ad5/F35-APE1 siRNA induced a slight increase in apoptotic cells compared with Ad5/F35EGFP, while Ad5/F35-APE1 siRNA increased significantly cell apoptosis induction by cisplatin. These results demonstrate that the combination of Ad5/F35-APE1 siRNA and cisplatin induces cell apoptosis in A2780 and CP70 cells in a supraadditive manner.
Cell cycle perturbations after Ad5/F35-APE1 siRNA treatment in vitro. An analysis of cell cycle perturbations was performed in A2780 and CP70 cells which were divided into four groups: a) Ad5/F35-EGFP 20 MOI, an empty adenoviral vector as control group, b) Ad5/F35-APE1 siRNA $20 \mathrm{MOI}, \mathrm{c}) \mathrm{Ad} 5 / \mathrm{F} 35-\mathrm{EGFP} 20 \mathrm{MOI}+$ cisplatin $\left(\mathrm{IC}_{50}\right.$ concentrations), and d) Ad5/F35-APE1 siRNA $20 \mathrm{MOI}+$ cisplatin ( $\mathrm{IC}_{50}$ concentrations). After $24 \mathrm{~h}$ infection of Ad5/F35-EGFP or Ad5/F35-APE1 siRNA, cisplatin of $\mathrm{IC}_{50}$ concentrations were added to A2780 and CP70 cell lines. Cells were collected and cell cycle status analyzed by DNA content after $24 \mathrm{~h}$.

Flow cytometry analyses for cell cycle changes are shown in Fig. 8. Exposure to $\mathrm{IC}_{50}$ concentrations of cisplatin resulted in accumulation of A2780 in G2/M phase, while caused S phase arrest in $\mathrm{CP} 70$, the cisplatin resistant cells. In Ad5/F35-APE1 siRNA-treated and untreated cells exposed to cisplatin, it was observed that A2780 cell line was arrested at 
A

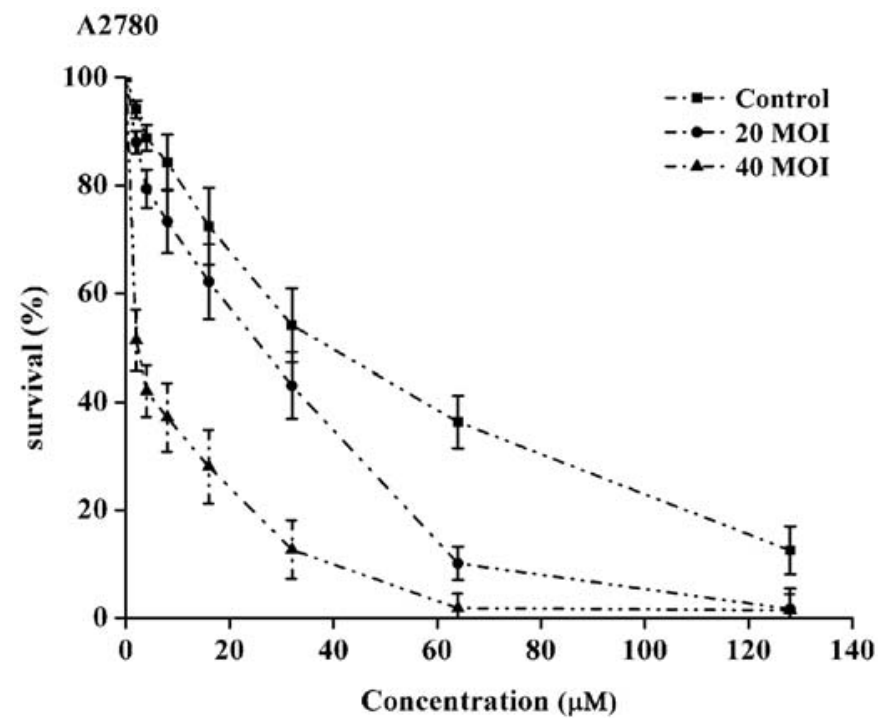

B

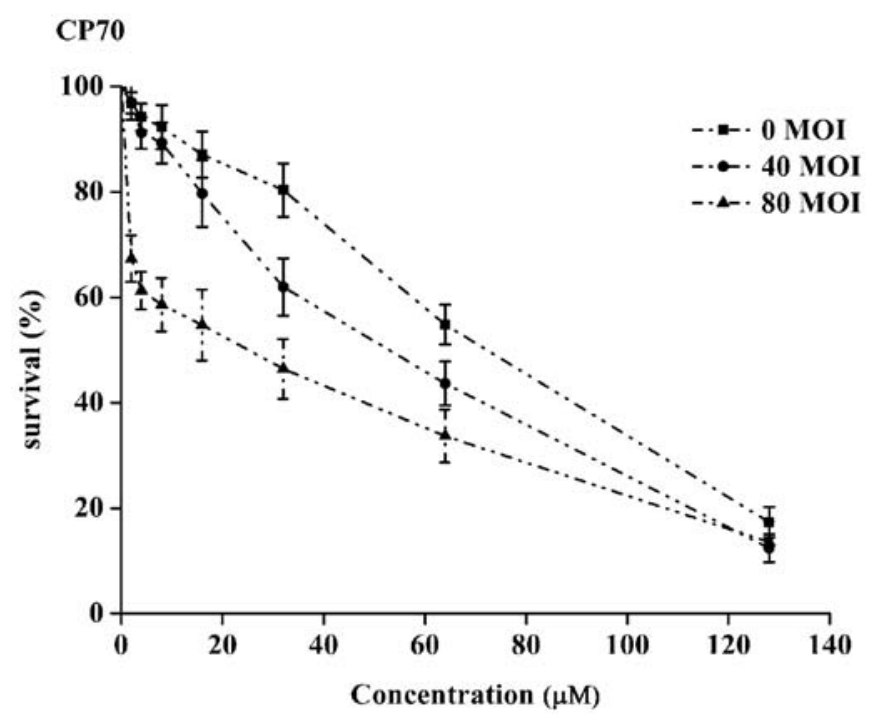

Figure 6. siRNA supression of APE1/Ref-1 produces greater sensitivity in A2780 and CP70 cell lines. MTT assays were used to determine the cell survival. The A2780 cell lines treated with APE1-siRNA had $\mathrm{IC}_{50}$ values ranging from $6.70 \mu \mathrm{M}$ to $1.74 \mu \mathrm{M}$ cisplatin compared with $15.81 \mu \mathrm{M}$ for control A2780 cells. The CP70 cell lines treated with APE1-siRNA had 1.62-4.63-fold enhancements in cisplatin sensitivity $(\mathrm{p}<0.05)$.

A

Control

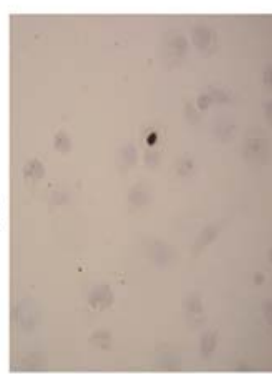

A2780
B

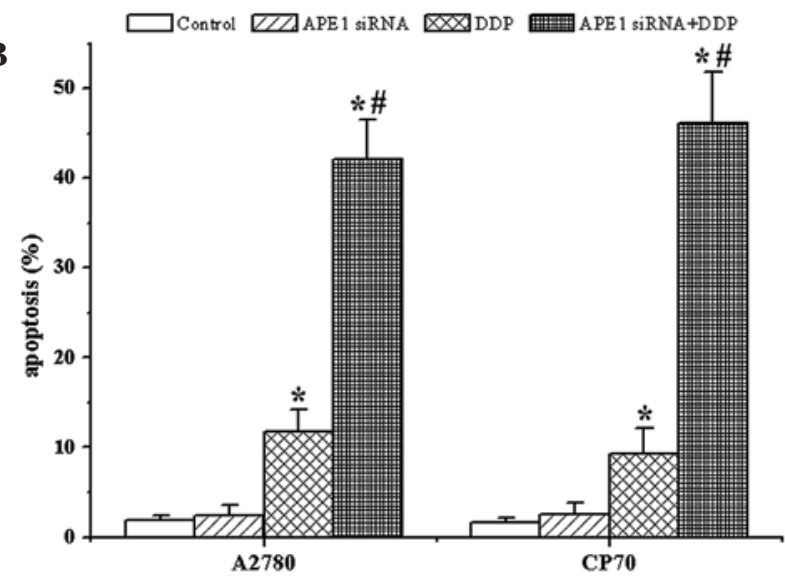

G0/G1 phase $(\mathrm{p}<0.05)$. In contrast, a significant increase in $\mathrm{S}$ phase was observed in the CP70 cell line after combined APE1 siRNA and cisplatin treatment $(\mathrm{p}<0.05)$.
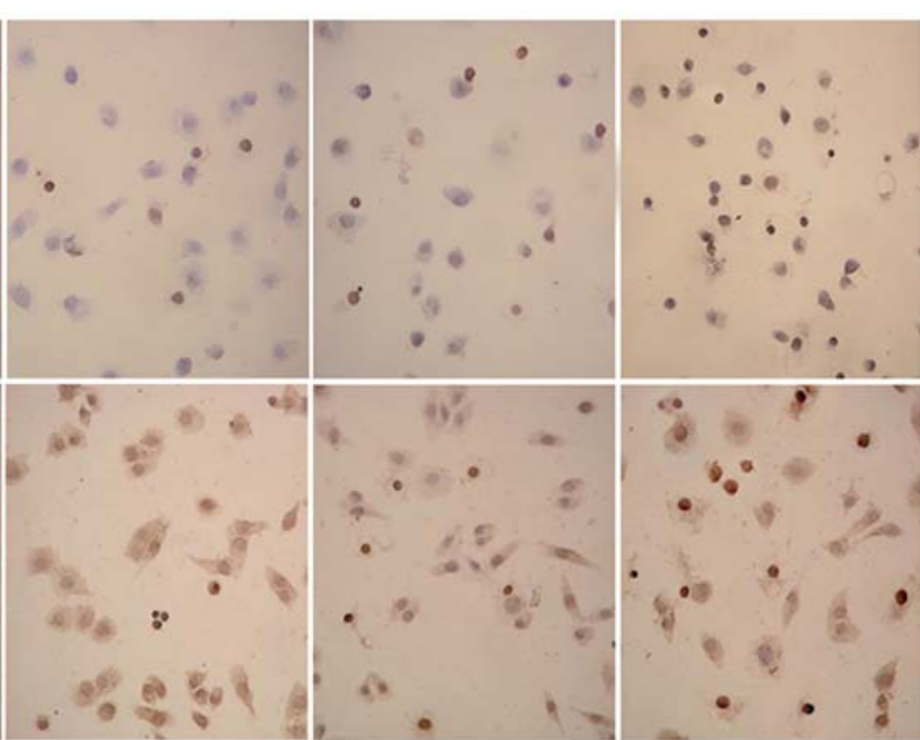

Figure 7. A, Combined treatment with APE1 siRNA and cisplatin-induced apoptosis in A2780 and CP70 cell lines. A2780 and CP70 cells were treated with Ad5/F35-APE1 siRNA at $40 \mathrm{MOI}$; $48 \mathrm{~h}$ after infection, cells were treated with cisplatin ( $\mathrm{IC}_{50}$ concentration), and apoptosis was determined $24 \mathrm{~h}$ after cisplatin treatment by TUNEL staining. B, Bar graghs represent the mean values of triplicate determinations $\pm \mathrm{SD}$. ${ }^{*} \mathrm{p}<0.05$ : versus control; ${ }^{*} \mathrm{p}<0.01$ : versus DDP.

\section{Discussion}

Platinum-based drugs are among the most active anticancer agents available and are used widely for the treatment of a variety of human solid tumors. The cytotoxic lesion of platinating agents is considered to be the platinum intrastrand crosslink that forms on DNA, although treatment activates a number of signal transduction pathways. The emergence of 


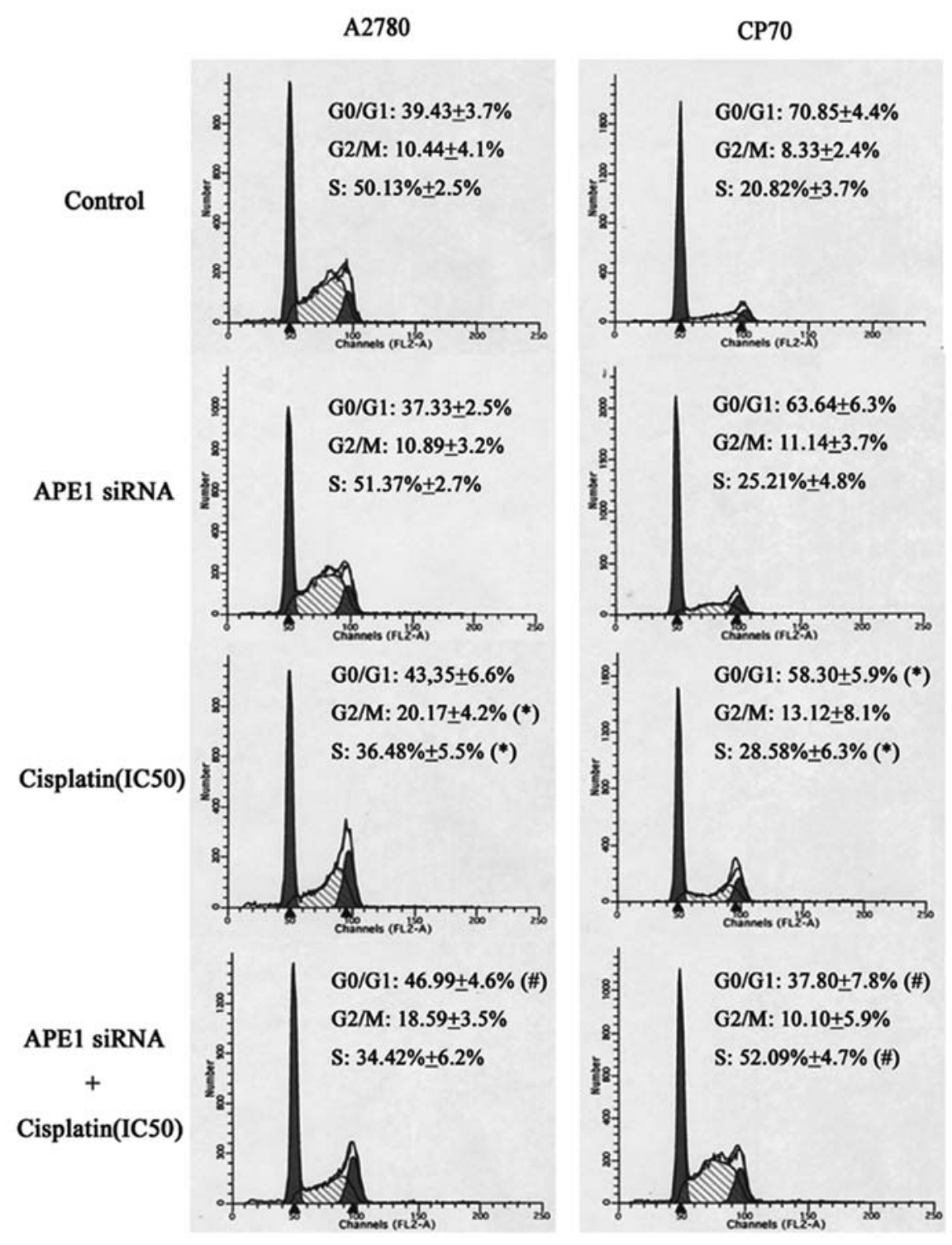

Figure 8. Analysis of relative cellular DNA content by flow cytometry. The relative DNA content of A2780 and CP70 cell lines following treatment with or without APE1 siRNA and/or cisplatin was analyzed. The population of cells determined from the relative DNA content is shown in each panel for each treatment condition. The results are representative of three independent determinations. The results are expressed as mean \pm standards (SD) of at least three independent experiments. The symbols $(*)$ denote significant difference $(\mathrm{p}<0.05)$ from control group $(\#)$ denote significant difference $(\mathrm{p}<0.05)$ from cisplatin group.

cisplatin resistance is a major stumbling block to the successful treatment of ovarian cancer. Both acquired and intrinsic resistance can be caused by a number of cellular adaptations, including reduced uptake, inactivation by glutathione and other anti-oxidants, and increased levels of DNA repair or DNA tolerance (3).

Repair of DNA damage is vital for maintaining genomic stability and hence crucial for cell survival. Therefore, reducing the DNA repair capability of cancer cells could enhance cytotoxicity of radio/chemotherapy. In addition, the expression and/or upregulation of DNA repair enzymes can contribute to the resistance of tumor cells in therapy where they are able to repair their DNA and escape the deleterious effects of treatment. One of these enzymes includes DNA repair enzymes, such as APE1 gene. APE1/Ref-1 is a ubiquitous bifunctional protein. APE1/Ref-1 is abundant in human cells and accounts for nearly all of the abasic site cleavage activity observed in cellular extracts (14). As a redox factor, APE1/ Ref- 1 can reduce a conserved cysteine residue in members of the Jun/Fos and related not only activating transcription factor/cAMP-responsive element binding protein families of proteins but also facilitating the formation of heterodimers and homodimers that bind to transcriptional regulatory elements containing activator protein 1 (AP-1). Importantly, APE1/Ref-1, by both redox-dependent and -independent mechanisms, also functions as a transcriptional coactivator for different transcription factors either ubiquitous (i.e., AP-1, Egr-1, NF-кB, p53 and HIF) or tissue-specific (i.e., PEBP-2, Pax-5 and -8, and TTF-1), in controlling different cellular processes such as apoptosis, proliferation, and differentiation (15).

APE1/Ref-1 appears to form a unique link among the DNA BER pathway, cancer, transcription factor regulation, oxidative signaling, and cell-cycle control. It is reasonable to 
postulate that APE1/Ref-1 may contribute to the molecular mechanism of resistance to platinum chemotherapy.

Recent evidence indicated that APE1/Ref-1, the key enzyme in BER pathway, may be a crucial determinant of chemotherapy sensitivity (16-22). In several tumors, APE1/ Ref-1 subcelluar localization has been demonstrated to have a prognostic value or to correlate with aggressiveness $(16,23,24)$. Therefore, it is somewhat controversial whether APE1 is correlated with platinum resistance in ovarian cancer (25).

In the present study, we assessed the role of APE1/Ref-1 in platinum resistance in primary ovarian tumors as well as ovarian cancer cell lines. It was found that the expression levels of APE1/Ref-1 gene were correlated with response to platinum-based chemotherapy. Non-responding cases showed higher level of APE1/Ref-1 expression compared with responding patients. Non-platinum-responding patients exhibited more disperse cytoplasm staining compared with patients responding to platinum. Thus, we used cell lines of ovarian cancer A2780 and stable cisplatin-resistant subline CP70, which exhibits variable levels of cisplatin resistance (between 15.81 and $64.19 \mu \mathrm{M}$ ) to investigate the mechanisms of cellular accumulation of cisplatin. Similarly, the expression of APE1/Ref-1 protein was obviously different in A2780 and CP70 cell lines. The predominant pattern of APE1/Ref-1 expression in A2780 cell line was nuclear. By contrast, mixed nuclear/cytoplasmic expression was observed in CP70 cell line. Both by immunohistochemistry and Western blot, APE1 protein expression level was noticeably higher in CP70 cell line than A2780 cell line. Analysis of Western blot demonstrated that CP70 cells displayed a 1.3-fold higher APE1 overexpression cmpared with A2780 cells.

According to these observations, it was shown that the APE1/Ref-1 overexpression is correlated with platinum resistance. It could be hypothesized that the exposure of chemotherapeutic agents might stimulate tumor cells to upregulate the levels of DNA repair proteins in order to repair DNA damage. Consistently with this hypothesis, APE1/Ref-1 content showed an increased trend in a dosedependent manner after different durations of cisplatin, in both cells lines. Treatment of cisplatin resistant cell line with cisplatin was associated with more significant increase in APE1/Ref-1 protein level compared with the parent sensitive cell line. The results may be due to chemo-resistance of tumor cells that have higher DNA repair capability. Similarly, Minisini and colleagues observed that patients with breast cancer showing high topoisomerase II $\alpha$ expression and lower APE1/Ref-1 nuclear expression were associated with favorable outcome (16). It is proposed that higher expression of molecular targets of chemotherapy and higher genetic instability due to the lack of DNA repair systems could attribute to making DNA damaging agents more effective in killing tumor cells.

With the increasing understanding of the molecular mechanism of chemotherapy resistance, more and more gene therapies emerge on cancer treatment which is being specifically directed toward molecular pathways that underlie the malignant phenotype. The above-described research indicates that APE1/Ref-1 activity may be critical to platinum resistance; we have studied whether we could increase cisplatin sensitivity by downregulating APE1/Ref-1 expression. To accomplish this goal, we suppressed APE1/Ref-1 expression by using silencing RNA targeting technology in A2780 and CP70 cell lines.

The APE1 siRNA expression vector, entitled Ad5/F35APE1 siRNA, constructed by De-Bing Xiang, could inhibit APE1 expression and AP endonuclease activity in a dosedependent manner (13). In this study, APE1 was supressed from 80 to $95 \%$ at doses of 20-40 MOI Ad5/F35-APE1 siRNA. It is proposed that infection with Ad5/F35-APE1 siRNA would potentiate platinum-induced DNA damage and enhance cytotoxicity of platinum. To test this hypothesis, the effect of Ad5/F35-APE1 siRNA on sensitive (A2780) and cisplatin-resistant (CP70) ovarian cancer cell lines was investigated and compared to cisplatin sensitivity. Our findings here demonstrate that reduced levels of APE1 dramatically enhance the cisplatin sensitivity of A2780 and CP70 cell lines. $\mathrm{IC}_{50}$ concentrations of cisplatin were 9.09- (A2780) or 4.63-fold (CP70) lower than those for cisplatin (MTT assay). Our results are supported by those of others in that the suppression of APE1 results in hypersensitivity to chemotherapeutic agents $(10,26,27)$. Additionally, targeted reduction of Ape1/Ref-1 protein by specific anti-sense oligonucleotides renders mammalian cells hypersensitive to methylmethane sulfonate (MMS), $\mathrm{H}_{2} \mathrm{O}_{2}$, bleomycin, temozolomide (TMZ) and gemcitabine $(22,28,29)$. Moreover, Robertson and colleagues found that elevated expression of APE1 in testicular cancer cell lines results in resistance to certain therapeutic agents, such as bleomycin and radiation (21).

We also examined the issue of whether the treatment with APE1 siRNA enhanced cisplatin sensitivity was due to an increase in apoptotic cell death. The TUNEL results showed that a reduction in APE1/Ref-1 coincided with an increase in apoptosis which was clearly demonstrated in siRNA-control cells. A relatively high rate of apoptosis after exposure to $\mathrm{IC}_{50}$ of cisplatin was observed in both A2780 and CP70 cell lines after the APE1 siRNA treatment. It was noted that this increased apoptosis was markedly higher in resistant CP70 cells compared with A2780 cells. There is further evidence that APE1 is involved in apoptosis. A 34-kDa protein, which was isolated from apoptotic human leukemia cells induced with camptothecin, was identified as an N-truncated form of APE1 lacking residues 1-35 (-34 APE1) (30). Additionally, another hypothesis on the APE1 role in apoptosis is based on the finding that APE1 displays endonuclease activity towards AP sites in single-stranded DNA (31).

The major cytotoxic lesion induced by platinum drugs is considered to be platination of the DNA. One of the early effects of the platination of DNA is a reduction in the rate of DNA synthesis and a consequent slow-down in the traverse of cells through the $\mathrm{S}$ phase of their cycle and subsequently, there is a dose-dependent arrest in G2. To study the drug resistance mechanism in which APE1/Ref-1 might be involved, we analyzed the status of the cell cycle on A2780 and CP70 cell lines treated with Ad5/F35-APE1 siRNA and cisplatin. It was observed that, following exposure of cisplatin, supression of APE1/Ref-1 is able to cause an arrest of cells in the G0/G1 phase in the sensitive cell line A2780 compared with untreated cells. In contrast, supression of APE1/Ref-1 in resistance cell line CP70 showed accumulation $S$ phase, which paralleled the drop in DNA synthesis. 
DNA damage arising from exposure to cytotoxic agents usually activates cell cycle checkpoints, which inhibit cell cycle progression by decreasing the activities of Cdks leading to cell cycle arrest at the G1 and G2/M phases. The cell cycle arrest at these phases allows DNA repair and prevents DNA replication or mitosis in the presence of damaged chromosomes. Non-reparable damage will trigger apoptosis under certain circumstances. Treated cells arrest in $\mathrm{S}$ phase with a complete withdrawal of cells from $\mathrm{G} / \mathrm{M}$ phase, which indicates that the effect on $\mathrm{G} 2 / \mathrm{M}$ checkpoints, if any, is overridden by the strong inhibition of DNA and RNA synthesis. Previous flow cytometric studies have indicated that the effect of APE1 siRNA on cisplatin sensitivity may be partly due to the modulation of the cell cycle, as a result of cellular response to DNA damage. New data demonstrate that APE1 affects cell growth by directly acting on RNA quality control mechanisms, thus affecting gene expression through post-transcriptional mechanisms (32). Future research is necessary in this area to identify the relationship between APE1 and cell cycle.

Although little is known of the mechanism of APE1/ Ref-1 impact on cisplatin resistance, some studies have provided us useful clues to understand it. It was shown that potent downregulation of APE1/Ref-1 with siRNA arrests cell proliferation and causes apoptosis with accumulation of abasic DNA damage in several human cell lines (33). APE1/Ref-1 has been implied to have a key role in regulation of $\mathrm{p} 53$ transcriptional activity by both redox-dependent and independent means (34), and the ability of p53 to induce apoptosis is affected by APE1/Ref-1 levels $(34,35)$. A potential link has been found between APE1/Ref-1 expression and p53 status in different tumors with their resistance to chemotherapeutic drugs (36). Recently, Chattopadhyay and colleagues provided some evidence that APE1 is a potential target for the drug sensitization of tumor cells. Their studies show that APE1 stably interacts with Ybox-binding protein 1 (YB-1) leading to the activation of the multidrug resistance gene MDR1. APE1 downregulation sensitizes MDR1-overexpressing tumor cells to cisplatin or doxorubicin, showing APE1's critical role in YB-1mediated gene expression and, thus, drug resistance in tumor cells (37).

Although a vast amount of evidence indicate that APE1/Ref-1 has a crucial impact on drug resistance, in this study, we could not distinguish which function of APE1/Ref-1 is essential for survival. Several studies have focused on some small molecules that blocked APE1 DNA repair function or its redox function, respectively, to explore the effect of APE1 or Ref-1 on the cancer cell response to chemotherapeutic agents and radiotherapy. It has emerged that some small molecules blocked APE1/Ref-1 DNA repair function, or its redox function, such as methoxyamine (MX) and 7-nitroindole-2-carboxylic acid (NCA), indirect and direct inhibitor of APE1/Ref-1's DNA repair activity, respectively, and lucanthone, direct inhibitor of APE1/Ref-1 repair activity (28). For example, lucanthone sensitizes breast cancer cells to methylating agents (38). These findings suggest that antiresistance chemotherapeutic targeting AP endo activity is pharmacologically tractable and potentially efficacious. Additionally, it has been confirmed that soy isoflavones, resveratrol and E3330 have effects on perturbing APE1/Ref-1 levels/function $(21,28,35,39)$.

In summary, our observations in this study on the A2780 and CP70 cell lines provide proof of supression of APE1/Ref-1 level/function, which might be a strategy to overcome cisplatin resistance in primary ovarian cancer. APE1/Ref-1 appears to form a unique link between the BER pathway, cancer, transcription factor regulation, oxidative signaling and cell-cycle control. This characteristic may prove to be a valuable anti-resistance chemotherapeutic target. Furthermore, the use of both APE1/Ref-1 repair and/or redox inhibitors as single agent treatments or in conjunction with standard chemotherapy and ionizing radiation is an area that is unexplored to date and yet important to investigate in certain cancer cells showing inherent resistance to chemotherapy.

\section{Acknowledgements}

We thank Dr Debin Xiang for providing Ad5/F35-APE1 siRNA and technical assistance during this study. This research was supported by grants from the National Natural Science Foundation of China (30672235) and the Military Medical Science Foundation of China (06M260).

\section{References}

1. http://www.cancer.org/docroot/STT/content/STT_1x_Global_ Cancer_Facts_and_Figures_2007_08.asp

2. Yakirevich E, Sabo E, Naroditsky I, Sova Y, Lavie O and Resnick MB: Multidrug resistance-related phenotype and apoptosis-related protein expression in ovarian serous carcinomas. Gynecol Oncol 100: 152-159, 2006.

3. Rabik CA and Dolan ME: Molecular mechanisms of resistance and toxicity associated with platinating agents. Cancer Treat Rev 33: 9-23, 2007.

4. Evans AR, Limp-Foster M and Kelley MR: Going APE over Ref-1. DNA Repair (Amst) 461: 83-108, 2000.

5. Chou KM and Cheng YC: An exonucleolytic activity of human apurinic/apyrimidinic endonuclease on 31 mispaired DNA. Nature 415: 655-659, 2002.

6. Chou KM, Kukhanova M and Cheng YC: A novel action of human apurinic/apyrimidinic endonuclease: excision of 1-configuration deoxyribonucleoside analogs from the 3 ' termini of DNA. J Biol Chem 275: 31009-31015, 2000.

7. Tanner B, Grimme S, Schiffer I, Heimerdinger C, Schmidt M, Dutkowski P, Neubert S, Oesch F, Franzen A, Kolbl H, Fritz G, Kaina B and Hengstler JG: Nuclear expression of apurinic/ apyrimidinic endonuclease increases with progression of ovarian carcinomas. Gynecol Oncol 92: 568-577, 2004.

8. Schindl M, Oberhuber G, Pichlbauer EG, Obermair A, Birner P and Kelley MR: DNA repair-redox enzyme apurinic endonuclease in cervical cancer: Evaluation of redox control of HIF1alpha and prognostic significance. Int J Oncol 19: 799-802, 2001.

9. Yoo DG, Song YJ, Cho EJ, Lee SK, Park JB, Yu JH, Lim SP, Kim JM and Jeon BH: Alteration of APE1/Ref-1 expression in non-small cell lung cancer: the implications of impaired extracellular superoxide dismutase and catalase antioxidant systems. Lung Cancer 60: 277-284, 2001.

10. Wang D, Luo M and Kelley MR: Human apurinic endonuclease 1 (APE1) expression and prognostic significance in osteosarcoma: enhanced sensitivity of osteosarcoma to DNA damaging agents using silencing RNA APE1 expression inhibition. Mol Cancer Ther 3: 679-686, 2004.

11. Di Maso V, Avellini C, Croce LS, Rosso N, Quadrifoglio F, Cesaratto L, Codarin E, Bedogni G, Beltrami CA, Tell G and Tiribelli C: Subcellular localization of APE1/Ref-1 in human hepatocellular carcinoma: possible prognostic significance. Mol Med 13: 89-96, 2007.

12. Puglisi F, Barbone F, Tell G, Aprile G, Pertoldi B, Raiti C, Kelley MR, Damante G, Sobrero A, Beltrami CA and Di Loreto C: Prognostic role of APE/Ref-1 subcellular expression in stage IIII breast carcinomas. Oncol Rep 9: 11-17, 2002. 
13. Xiang DB, Chen ZT, Wang D, Li MX, Xie JY, Zhang YS, Qing Y, Li ZP and Xie J: Chimeric adenoviral vector AD5/F35-mediated APE1 siRNA enhances sensitivity of human colorectal cancer cells to radiotherapy in vitro and in vivo. Cancer Gene Ther 15: 625-635, 2008

14. Demple B and Sung J-S: Molecular and biological roles of APE1 protein in mammalian base excision repair. DNA Repair (Amst) 4: 1442-1449, 2005

15. Tell G, Damante G, Caldwell D and Kelley MR: The intracellular localization of APE1/Ref-1: more than a passive phenomenon? Antioxid Redox Signal 7: 367-384, 2005.

16. Minisini AM, Di Loreto C, Mansutti M, Artico D, Pizzolitto S, Piga A and Puglisi F: Topoisomerase IIalpha and APE/Ref-1 are associated with pathologic response to primary anthracyclinebased chemotherapy for breast cancer. Cancer Lett 224: 133-139, 2005 .

17. Silber JR, Bobola MS, Blank A, Schoeler KD, Haroldson PD, Huynh MB and Kolstoe DD: The apurinic/apyrimidinic endonuclease activity of APE1/Ref-1 contributes to human glioma cell resistance to alkylating agents and is elevated by oxidative stress. Clin Cancer Res 8: 3008-3018, 2002.

18. Farkasova T, Gurska S, Witkovsky V and Gabelova A: Significance of amino acid substitution variants of DNA repair genes in radiosusceptibility of cervical cancer patients; a pilot study. Neoplasma 55: 330-337, 2008.

19. Bobola MS, Emond MJ, Blank A, Meade EH, Kolstoe DD, Berger MS, Rostomily RC, Silbergeld DL, Spence AM and Silber JR: Apurinic endonuclease activity in adult gliomas and time to tumor progression after alkylating agent-based chemotherapy and after radiotherapy. Clin Cancer Res 10: 7875-7883, 2004 .

20. Koukourakis MI, Giatromanolaki A, Kakolyris S, Sivridis E, Georgoulias V, Funtzilas G, Hickson ID, Gatter KC and Harris AL: Nuclear expression of human apurinic/apyrimidinic endonuclease (HAP1/Ref-1) in head-and-neck cancer is associated with resistance to chemoradiotherapy and poor outcome. Int J Radiat Oncol Biol Phys 50: 27-36, 2001.

21. Robertson KA, Bullock HA, Xu Y, Tritt R, Zimmerman E, Ulbright TM, Foster RS, Einhorn LH and Kelley MR: Altered expression of APE1/Ref-1 in germ cell tumors and overexpression in NT2 cells confers resistance to bleomycin and radiation. Cancer Res 61: 2220-2225, 2001.

22. Bobola MS, Finn LS, Ellenbogen RG, Geyer JR, Berger MS Braga JM, Meade EH, Gross ME and Silber JR: Apurinic/ apyrimidinic endonuclease activity is associated with response to radiation and chemotherapy in medulloblastoma and primitive neuroectodermal tumors. Clin Cancer Res 11: 74057414,2005

23. Yang S, Irani K, Chun S and Meyskens FL: Expression of apurinic/apyrymidinic endonuclease/redox effector-1 (APE/Ref-1) is elevated with progression of human melanoma and the therapeutic potential of APE/Ref-1 inhibitors. Proc AACR (abs.) 1043, 2005.

24. Puglisi F, Aprile G, Minisini AM, Barbone F, Cataldi P, Tell G, Kelley MR, Damante G, Beltrami CA and Di Loreto C: Prognostic significance of APE/Ref-1 subcellular localization in non-small cell lung carcinomas. Anticancer Res 21: 4041-4049, 2001

25. Freitas S, Moore DH, Michael Ha and Kelley MR: Studies of apurinic/apyrimidinic endonuclease/ref-1 expression in epithelial ovarian cancer: Correlations with tumor progression and platinum resistance. Clin Cancer Res 9: 4689-4694, 2003.
26. McNeill DR and Wilson DM 3rd: A dominant-negative form of the major human abasic endonuclease enhances cellular sensitivity to laboratory and clinical DNA-damaging agents. Mol Cancer Res 5: 61-70, 2007.

27. Vasko MR, Guo C and Kelley MR: The multifunctional DNA repair/redox enzyme APE/Ref-1 promotes survival of neurons after oxidative stress. DNA Repair (Amst) 4: 367-379, 2005.

28. Fishel ML and Kelley MR: The DNA base excision repair protein APE/Ref-1 as a therapeutic and chemopreventive target. Mol Aspects Med 28: 375-395, 2007.

29. Lau JP, Weatherdon KL, Skalski V and Hedley DW: Effects of gemcitabine on APE/Ref-1 endonuclease activity in pancreatic cancer cells, and the therapeutic potential of antisense oligonucleotides. Br J Cancer 91: 1166-1173, 2004

30. Yoshida A, Urasaki Y, Waltham M, Bergman AC, Pourquier P, Rothwell DG, Inuzuka M, Weinstein JN, Ueda T, Appella E, Hickson ID and Pommier Y: Human apurinic/apyrimidinic endonuclease (APE1) and its n-terminal truncated form (AN34) are involved in DNA fragmentation during apoptosis. J Biol Chem 278: 37768-37776, 2003

31. Dyrkheevaa NS, Khodyreva SN and Lavrik OI: Multifunctional human apurinic/apyrimidinic endonuclease 1: Role of additional functions. Mol Biol 41: 402-416, 2007.

32. Vascotto C, Fantini D, Romanello M, Cesaratto L, Deganuto M, Leonardi A, Radicella JP, Kelley MR, D'Ambrosio C, Scaloni A, Quadrifoglio F and Tell G: APE1/Ref-1 interacts with NPM1 within nucleoli and plays a role in the rRNA quality control process. Mol Cell Biol 29: 1834-1854, 2009.

33. Fung $\mathrm{H}$ and Demple B: A vital role for $\mathrm{APE} / \mathrm{Ref}-1$ protein in repairing spontaneous DNA damage in human cells. Mol Cell 17: 463-470, 2005

34. Gaiddon C, Moorthy NC and Prives C: Ref-1 regulates the transactivation and pro-apoptotic functions of p53 in vivo. EMBO J 18: 5609-5621, 1999.

35. Raffoul JJ, Banerjee S, Singh-Gupta V, Knoll ZE, Fite A, Zhang H, Abrams J, Sarkar FH and Hillman GG: Down-regulation of apurinic/apyrimidinic endonuclease $1 /$ redox factor-1 expression by soy isoflavones enhances prostate cancer radiotherapy in vitro and in vivo. Cancer Res 67: 2141-2149, 2007.

36. Amira Zaky CB and Izumi T: Regulation of the human APendonuclease (APE1/Ref-1) expression by the tumor suppressor 553 in response to DNA damage. Nucleic Acids Res 36: 1555-1566, 2008

37. Chattopadhyay R, Das S, Maiti AK, Boldogh I, Xie J, Hazra TK, Kohno K, Mitra S and Bhakat KK: Regulatory role of human ap-endonuclease (APE/Ref-1) in YB-1-mediated activation of multi drug resistance gene MDR1. Mol Cell Biol 28: 7066-7080, 2008.

38. Luo M, Caldwell D, Xu Y, He Y, Reed A, Handa H and Kelley MR: Inhibition of the human apurinic/apyrimidinic endonuclease DNA base excision repair enzyme/redox factor (APE/Ref-1) using small molecule redox and repair inhibitors: Therapeutic implications. Proc AACR 45: 703-704, 2004.

39. Hiramoto M, Shimizu N, Nishi T, Shima D, Aizawa S, Tanaka H, Hatakeyama M, Kawaguchi $\mathrm{H}$ and Handa H: High-performance affinity beads for identifying anti-NF-kappa B drug receptors. Methods Enzymol 353: 81-88, 2002. 